\title{
Standard area diagram set for bacterial spot assessment in fruits of yellow passion fruit
}

\author{
Anne Pinheiro Costa ${ }^{1}$, Márcio de Carvalho Pires ${ }^{2}$, José Ricardo Peixoto², \\ Luiz Eduardo Bassay Blum³, Fábio Gelape Faleiro ${ }^{4}$
}

\begin{abstract}
This study developed and validated a standard area diagram set (SADs) for severity assessment of bacterial spot (Xanthomonas axonopodis pv. passiflorae) in fruits of yellow passion fruit (Passiflora edulis). The SADs consisted of eight severity levels $(1 \% ; 3 \% ; 5 \% ; 10 \% ; 21 \%$; $38 \%$; $65 \%$; and $80 \%$ ). For its validation, 20 raters, who initially estimated the disease severity without the aid of the SADs, were divided into groups (G1 and G3, inexperienced; G2 and G4, experienced). Subsequently, G1 and G2 performed the second evaluation without the proposed SADs, and G3 and G4 completed the second evaluation using the proposed SADs. The accuracy and precision of the assessments were determined by simple linear regression and by the Lin's concordance correlation coefficient. The increase in the accuracy was confirmed by the reduction in the constant and systematic errors, indicating that the estimated severities were close to the actual values when the SADs was used. Inexperienced raters benefited the most from the use of the SADs, and $60 \%$ and $100 \%$ of them presented constant and systematic error-free estimates, respectively. Precision increased with the increase in the coefficient of determination, the reduction in absolute errors, and the increase in the reproducibility of the estimates between pairs of raters. Index terms: Passiflora edulis Sims, Xanthomonas axonopodis pv. passiflorae, phytopathometry, fruits.
\end{abstract}

\section{Escala diagramática para a avaliação da bacteriose em frutos do maracujazeiro azedo}

Corresponding author: annecosta@gmail.com

Received: April 13, 2018 Accepted: September 06, 2018

Copyright: All the contents of this journal, except where otherwise noted, is licensed under a Creative Commons Attribution License.

\section{(cc) $\mathbf{E Y}$}

Resumo-Este estudo desenvolveu e validou uma escala diagramática para a avaliação da severidade da bacteriose (Xanthomonas axonopodis pv. passiflorae) em frutos do maracujazeiro-azedo (Passiflora edulis). A escala diagramática apresentou oito níveis de severidade $(1 \%, 3 \%, 5 \%, 10 \%$, $21 \%, 38 \%, 65 \%$ e $80 \%$ ). Para a sua validação, 20 avaliadores foram divididos em grupos (G1 e G3, sem experiência; G2 e G4, com experiência), que inicialmente estimaram a severidade da doença sem auxílio da escala. Posteriormente, G1 e G2 fizeram outra avaliação sem a escala, e G3 e G4 realizaram a avaliação com a escala proposta. A acurácia e a precisão das estimativas foram determinadas por regressão linear simples e pelo coeficiente de correlação de concordância de Lin. O incremento da acurácia foi observado pela redução dos erros constantes e sistemáticos, indicando que as severidades estimadas se aproximaram dos valores reais quando a escala foi utilizada. Os avaliadores inexperientes foram os mais beneficiados pelo uso da escala, sendo que $60 \%$ e $100 \%$ dos avaliadores apresentaram estimativas sem erros constantes e sistemáticos, respectivamente. $\mathrm{O}$ aumento da precisão foi verificado pelo incremento dos coeficientes de determinação, pela redução dos erros absolutos e pelo aumento da reprodutibilidade das estimativas entre pares de avaliadores. Termos para indexação: Passiflora edulis Sims, Xanthomonas axonopodis pv. passiflorae, fitopatometria, frutos.

\footnotetext{
${ }^{1}$ Biologist, D.Sc., University of Brasilia, Faculty of Agronomy and Veterinary Medicine, Brasilia-DF, Brazil. E-mail: annecosta@gmail.com. ${ }^{2}$ Agricultural Engineer, D.Sc., Professor, University of Brasilia, Faculty of Agronomy and Veterinary Medicine, Brasilia-DF, Brazil. E-mails: peixoto@unb.br; mcpires@unb.br

${ }^{3}$ Agricultural Engineer, Ph.D., Professor, Department of Plant Pathology, University of Brasilia, Institute of Biological Sciences, Brasilia-DF, Brazil. E-mail: luizblum@unb.br

${ }^{4}$ Agricultural Engineer, D.Sc., Researcher at Embrapa Cerrados. Brasilia-DF, Brazil. E-mail: fabio.faleiro@embrapa.br
} 


\section{Introduction}

Yellow passion fruit (Passiflora edulis Sims) stands out as the most cultivated and commercialized species of the genus Passiflora due to its fruit quality and yield (FALEIRO et al., 2011). However, this species is susceptible to several diseases, such as bacterial spot (Xanthomonas axonopodis pv. passiflorae), which is widespread in all producing regions, depreciating the fruit quality and value and reducing the crop's production cycle (JUNQUEIRA et al., 2016). Bacterial spot lesions on the fruit are large, with initial green and greasy appearance, which later becomes brown. They are circular or irregular in shape, with well-defined edges, which can coalesce and cause larger lesions (FISCHER; REZENDE, 2008). Initially, lesions are superficial; however, the pathogen can penetrate the pulp and promote its fermentation, resulting in fruit rotting (PERUCH et al., 2011).

Quantifying disease severity is fundamental in epidemiological studies (DE BEM et al., 2016) for the evaluation of control strategies (MARCUZZO et al., 2016) and identification of resistance sources (GYAWALI et al., 2018). In breeding programs of yellow passion fruit, this evaluation has been carried out using descriptive scales (KUDO et al., 2012; BATISTTI et al., 2013; VIANA et al., 2014; NOGUEIRA, 2016). These scales are subjective and do not allow adjusting the visual acuity when evaluating the severity levels (CAMPBELL; MADDEN, 1990), which impairs the precise quantification of the injured area (SANTOS et al., 2017). Conversely, diagrammatic scales or standard area diagram set (SADs) are valuable tools for the identification of variations in disease resistance among genotypes. When applying scales, the accuracy and precision of the disease severity estimates are significantly improved, resulting in fewer experimental errors (LAGE et al., 2015; DE PAULA et al., 2016; SANTOS et al., 2017). Consequently, heritability estimates for disease resistance are more reliable, which increases the potential gains from selective breeding (VIEIRA et al., 2014).

The use of SADs has contributed to increasing the accuracy and precision of estimates of disease severity caused by Xanthomonas to other plants, such as grapes (NASCIMENTO et al., 2005), peach (CITADIN et al., 2008), common beans (LIMA et al., 2013), orange (BRAIDO et al., 2015), and tomato (DUAN et al., 2015). Despite the great relevance of diseases in yellow passion fruit crops, the only SADs validated for diseases quantification in this species is the one developed by Fischer et al. (2009) for the evaluation of anthracnose in fruits. Considering the lack of standardized methods to quantify the bacterial spot severity in this fruit, this work aimed to: (1) develop and validate a SADs for the evaluation of bacterial spot severity in yellow passion fruit; (2) compare the accuracy, precision, and agreement of disease severity estimates, with and without the aid of the SADs; and (3) compare the accuracy, precision, and agreement of the estimates of inexperienced and experienced raters.

\section{Material and methods}

\section{Development of the SADs}

Fifty fruits of yellow passion fruit (BRS Gigante Amarelo and Yellow Master FB200 commercial cultivars) showing symptoms of bacterial spot were collected at Paraná Farm commercial orchard, located in Nucleo Rural Pipiripau, Planaltina, DF (lat. 47²9'56,92” S; long. $15^{\circ} 30^{\prime} 15,08^{\prime \prime} \mathrm{W}$, and alt. $\left.955 \mathrm{~m}\right)$. The adaxial surface of each fruit was photographed with a digital camera (Canon Powershot SX40 HS, 12.1 megapixels; Canon Inc., Tóquio, Japão), set at $45 \mathrm{~cm}$ height from the fruit level. The resulting images were analyzed for the diseased area (necrotic + chlorotic), using the image analysis software IMAGE J (SCHNEIDER et al., 2012). The percentage of lesion area (\% lesion area) was determined by dividing the lesion area by the total fruit area.

The SADs' upper and lower limits were based on the minimum and maximum values of bacterial spot severity found in the image analysis of the 50 fruits. Intermediate levels were established following logarithmic increments (NUTTER; SCHULTZ, 1995). A standard fruit was used as the template, and diagrams with different severity levels were created using the IMAGE J software. The patterns of lesion distribution detected on the actual fruits were maintained.

\section{Validation of the SADs}

The SADs was validated using images of 50 fruits with different intensities of symptoms. Twenty raters (ten with previous experience and ten without previous experience in disease quantification) were selected and divided into four groups of five raters (G1 and G3, inexperienced; G2 and G4, experienced). Initially, each group estimated the disease severity, in percentage, for each of the 50 fruit images randomly organized, without the aid of the SADs (non-aided evaluation). Subsequently, the same images were presented to G1 and G2, who performed another non-aided evaluation, and to G3 and G4, who conducted the evaluation using the proposed SADs (SADs-aided evaluation).

The accuracy and precision of the raters were determined by linear regression between the actual severity (independent variable) and the visually estimated severity (dependent variable). The accuracy of estimates of each rater was determined by a t-test applied to the intercept of linear regression $(a)$ to verify if it was significantly different from 0 , and to the slope of the line $(b)$, to test if it was significantly different from $1(\mathrm{P} \leq 0.05)$. Intercept values significantly different from 0 indicate the presence of constant errors, whereas values of the slope of the line different from 1 indicate the presence of systematic errors (NUTTER; SCHULTZ, 1995). Consequently, the 
most accurate raters were those whose estimates provided linear regression equations with values of " $a$ " and " $b$ " not significantly different from 0 and 1 by the t-test.

The precision of estimates of each rater was obtained by the coefficient of determination of the regression analysis $\left(R^{2}\right)$ and the variance of absolute errors (the difference between estimated and actual severities) (KRANZ, 1988). Absolute errors were compared by the t-test $(\mathrm{P} \leq 0.05)$. Raters with higher values of $R^{2}$ were considered as of higher precision. Evaluations of the absolute errors considered the criteria used in disease quantification training programs [Distrain (TOMERLIN; HOWELL, 1988) and Disease.Pro (NUTTER; WORAWITLIKIT, 1989)], which classify raters as excellent (errors up to $5 \%$ ) or good (errors up to $10 \%$ ). The mean maximum error (absolute value) was also recorded for each group, indicating, in absolute value, the difference between the farthest estimate and the actual severity value. The reproducibility or inter-rater reliability was measured using the $R^{2}$ values for each pair of raters, based on estimates of non-aided evaluations and SADsaided evaluations (NUTTER; SCHULTZ, 1995).

Accuracy and precision (agreement) of the estimates of each rater, with and without the use of the SADs, was also determined based on the Lin's concordance correlation coefficient $\left(\mathrm{LCCC} ; \rho_{c}\right)$. The LCCC combines measures of accuracy and precision to assess the relational fit of pairs of observations to the concordance line $\left(45^{\circ}\right)$ (with intercept $=0$ and slope $=1$ ), or 1:1 line, and is defined by $\rho_{c}=C_{b} . r$. The element $C_{b}$ is a bias correction factor that measures how far the best-fit line deviates from $45^{\circ}$; therefore, it corresponds to a measure of accuracy. In its turn, $r$ is the correlation coefficient between the estimated severity (Y) and the actual severity (X), which measures the precision (variation) or the scattering of points around the best-fit line. When the perfect agreement between estimated and actual severity occurs, the points fall on the concordance line. As a result, $r=1, C_{b}=1$, and $\rho_{c}=$ 1 (LIN, 1989; BOCK et al., 2010).

Linear regressions and absolute errors analyses were performed using the Genes software (v. 1990.2017.37). The LCCC was calculated using the MedCalc software (v. 17.9.7).

\section{Results and discussion}

The bacterial spot severity recorded in yellow passion fruit naturally infected in the field was between $1 \%$ and $79.5 \%$. The observed lesions showed typical symptomatic patterns of the disease, with circular or irregular shape, brown color, and in most cases, they covered large areas of the fruit (FISCHER; REZENDE, 2008). From these disease severity ranges, a SADs was proposed, which was divided into eight severity levels
$(1 \%, 3 \%, 5 \%, 10 \%, 21 \%, 38 \%, 65 \%$, and $80 \%)$ (Figure $1)$. The high severity levels reported in this study are commonly observed in yellow passion fruit orchards due to the difficult control of this disease and the susceptibility of commercial cultivars to this bacterium (ISHIDA; HALFELD-VIEIRA, 2009). To better represent the severity values identified for the bacterial spot, the SADs composed of a larger number of diagrams are frequently used in pathosystems that involve the species Xanthomonas (NASCIMENTO et al., 2005; LIMA et al., 2013; DUAN et al., 2015), as established in this study.

The accuracy analysis was performed to verify the proximity between the values of estimated severity and actual severity (NUTTER; SCHULTZ, 1995). Figures 2 to 5 show the linear regressions obtained between the actual and estimated severities for all raters in evaluations 1 and 2. The accuracy of the estimates reduced in the second evaluation performed by G1, and the number of estimates with constant errors [i.e., intercept different from $0(P \leq 0.05)]$ increased. Conversely, the accuracy of raters who showed constant errors in the first evaluation in $\mathrm{G} 2$ increased in the second non-aided evaluation. In the SADs-aided groups, $60 \%$ and $40 \%$ of the raters in G3 and G4, respectively, had intercept values equal to 0 $(\mathrm{P} \leq 0.05)$ (Table 1). These results indicate a reduction of constant errors for all disease severity levels verified in the evaluation 1 (non-aided).

Regarding the slope of the line, $75 \%$ of the G1 raters had an improvement in the accuracy levels in the second evaluation, with a coefficient significantly equal to $1(\mathrm{P} \leq 0.05)$. In $\mathrm{G} 2$, the number of raters who had an increase in the accuracy was equal to those whose accuracy was reduced. Among the SADs-aided groups, G3 showed the highest percentage of raters with improvement in accuracy levels due to the significant reduction in the systematic errors of the estimates $(100 \%$ in G3 vs. $50 \%$ in G4). In this sense, inexperienced raters appear to benefit more by the use of the SADs than those of the other groups since $60 \%$ of the raters in G3 did not show systematic and constant errors (Table 1).

Mean $R^{2}$ values were high in all groups and evaluations (Table 1). One of the reasons for the raters' good performance may be the distribution pattern and size of bacterial spot lesions. According to Bock et al. (2010) and González-Domínguez et al. (2014), the accuracy and precision of estimates are directly influenced by the number of lesions in relation to the leaf area. The higher the number of lesions for a given area, the higher is the overestimation. Moreover, the general trend is to overestimate disease severity at severity levels lower than $10 \%$. Thus, diseases that result in fewer but larger lesions, such as bacterial spot, tend to be estimated with fewer errors than those that result in several but smaller lesions, regardless of the distribution pattern (KRANZ, 1988; HAU et al., 1989). 
In the second evaluation, the mean $R^{2}$ value did not increase in G1 and reduced in G2. Conversely, the use of the SADs increased the precision in G3 and G4. This increase was more significant in the group of inexperienced raters (G3), whose $R^{2}$ value increase from 0.85 (non-aided) to 0.93 (SADs-aided). In the experienced group (G4), precision increased from 0.91 to 0.94 (Table 1). These results indicate that, with the SADs, estimates were related to the actual value in both groups. They also show a greater increase in the precision for the inexperienced raters when compared with the experienced raters. Different studies have already compared the raters' performance, indicating the existence of diversity in the individual ability to assess the severity of a particular disease. Studies usually state that the use of the SADs may be more advantageous for inexperienced raters than experienced raters (FISCHER et al., 2009; YADAV et al., 2013; GONZÁLEZ-DOMÍNGUEZ et al., 2014; NUÑEZ et al., 2017). The use of the SADs for disease evaluation makes the assessment more accurate and precise as it guides the raters in the data collection. The SADs does not replace the experience and knowledge of characteristic symptoms of a pathogen or physiological stress. However, it can improve the efficiency of the inexperienced and experienced raters by providing a reference point for comparison (VENTURINI et al., 2015).

In addition to the determination coefficient, the good precision of raters can be detected by determining the absolute or residual error (the difference between estimated and actual severity). Regardless of the rater's experience, the precision increased with the use of the SADs, which was confirmed by the lower dispersion of data in the regression (Figures 2-5) and the reduction of absolute errors $(\mathrm{P} \leq 0.05)$ (Table 2$)$, resulting in differences between the SADs-aided and non-aided evaluations in the same group.

The distribution of errors of non-aided evaluations ranged from -12.3 to +32.7 (G1); -20.5 to +17.0 (G2); -37.0 to $+31.9(\mathrm{G} 3)$; and -16.8 to $+30.0(\mathrm{G} 4)$. In the second non-aided evaluation, errors ranged from -16.5 to +27 (G1) and -20.5 to +27.0 (G2). In SADs-aided evaluations, distribution of errors ranged from -20.5 to +25.7 and -28.4 to +24.2 in G3 and G4, respectively. The mean maximum error of the actual severity, in absolute value, decreased by $20.2 \%$ in the second evaluation performed by G1; conversely, in G2, an increase was observed. The mean maximum error reduced with the use of the SADs, corresponding to a $32.5 \%$-lower value for the inexperienced raters and $24.1 \%$-lower value for the experienced raters in relation to the non-aided evaluation (Table 3). The reduction in absolute errors in G3 and G4 demonstrates that the precision of the visual estimates increased with the use of the SADs. This increase indicates an approximation between the estimates of the lessaccurate and the more-accurate raters and corroborates studies previously reported (DE PAULA et al., 2016; CORREIA et al., 2017; NUÑEZ et al., 2017; SANTOS et al., 2017), considering that the proposed SADs aims to standardize the disease quantification.

$\mathrm{G} 1$ and $\mathrm{G} 2$ raters had greater absolute errors in the second evaluation, resulting in an increase in estimates with errors higher than $10 \%(-10$ to +10$)$ (Table 3$)$. SADs-aided evaluations had a decrease in the percentage of estimates with errors greater than $10 \%$ when compared with the non-aided evaluation. Thus, 89.6\% (G3) and 93.6\% (G4) of the estimates were concentrated within the range of $10 \%$, which is considered as satisfactory in studies on the SADs validation (NUTTER; WORAWITLIKIT, 1989). In SADs-aided evaluations, the percentage of estimates within the range of $5 \%(-5$ to +5$)$ was higher in G3 and G4, which indicates that the raters' estimates were closer to the actual severity value. Although such behavior was also detected in $\mathrm{G} 1$, this increase $(1.3 \%)$ was much more discreet than those observed for the SADs-aided groups (14.8\% and $16.9 \%$ for $\mathrm{G} 3$ and $\mathrm{G} 4$, respectively) (Table 3 ).

The precision of the evaluations was also analyzed by the reproducibility of the estimates among the raters, who had access to the same images sample, with and without the aid of the SADs. According to Belasque Junior et al. (2005), when the $R^{2}$ value of the comparison between two raters is close to 1.00 , raters' estimates are repeated. In the first evaluation, $R^{2}$ values of regressions of estimates between pairs of raters in G3 and G4 ranged from 0.72 to 0.87 (mean 0.80 ) and from 0.80 to 0.91 (0.85), respectively. In the second evaluation, $R^{2}$ values varied from 0.85 to $0.93(0.89)$ in $\mathrm{G} 3$, and from 0.85 to $0.96(0.91)$, in G4. The use of the SADs provided higher $R^{2}$ values for $100 \%$ and $90 \%$ of the combinations in G3 and $\mathrm{G} 4$, respectively, evidencing the increase in the precision of the estimates when using the SADs.

The $R^{2}$ and $r$ coefficients inform on the precision of an estimate. However, they do not report on the accuracy of a model (PEREIRA et al., 2008). The Lin's concordance correlation coefficient $\left(\rho_{c}\right)$, however, is the product of the elements precision $(r)$ and accuracy $\left(C_{b}\right)$, reflecting the degree of agreement between estimated and actual values (LIN, 1989). The Lin's concordance correlation coefficient confirmed the increments in the accuracy and precision of the raters, which were previously described for the SADs-aided evaluation. In the first evaluation, G1 and G2 had higher $\rho_{c}$ values, indicating that the values were closer to the actual values in relation to groups G3 and G4. Nevertheless, when using the SADs, the agreement between the actual and estimated severity values increased, as confirmed by the approximation between the best-fit line (between actual and estimated severity) and the 1:1 line (actual severity equal to the estimated severity) (Figures 4 and 5). $\rho_{c}$ values varied from 0.93 to 0.97 in G3 (mean of 0.94) and from 0.93 to 0.98 in G4 (mean of $0.95)$, representing an increase of $10.6 \%(\mathrm{G} 3)$ and $5.6 \%$ 
(G4) when compared with the non-aided evaluations of these groups (Table 4). No increase was observed for the agreement in the groups that performed the double nonaided evaluation (Table 4, Figures 2 and 3).

$r$ and $C_{b}$ values also increased in the SADs-aided evaluations, unlike the results of G1 and G2 (Table 4). Less accurate and precise raters benefited the most by the use of the SADs, showing the largest increments in the evaluated parameters. Thus, G3 exhibited a $4.3 \%$ and $6.5 \%$ increase in accuracy and precision, respectively, while G4 showed a $2.1 \%$ (accuracy) and $4.3 \%$ (precision) increase. Conversely, more accurate and/or precise raters did not respond as well to the use of the SADs as those who initially had less accurate and precise estimates. In fact, raters 14, 19, and 20 demonstrated a slight increase in errors (Table 2) and/or no increment or slight loss of accuracy, precision, and agreement (Table 4). These results indicate that the SADs helped standardize the evaluations of the several raters, as also reported by Yadav et al. (2013).

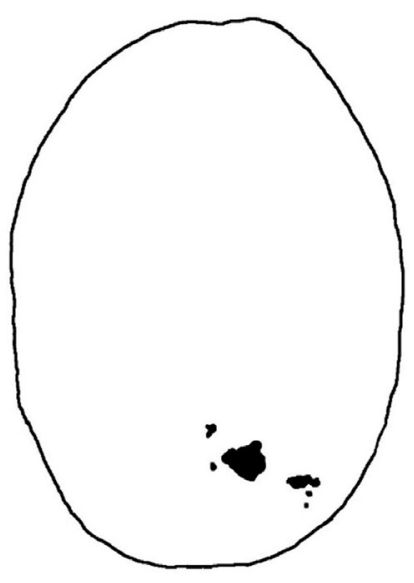

$1.0 \%$

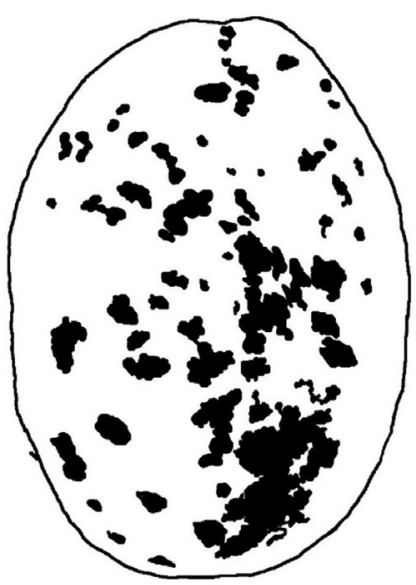

$21.0 \%$

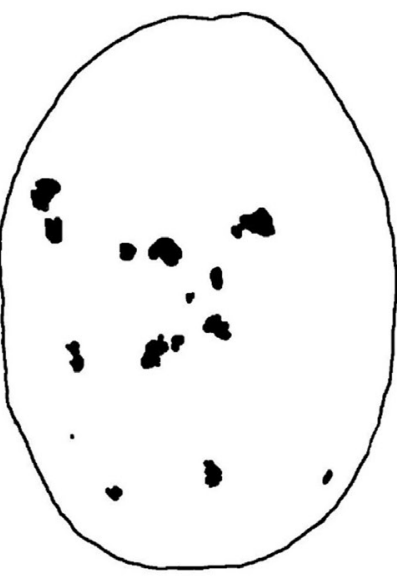

$3.0 \%$

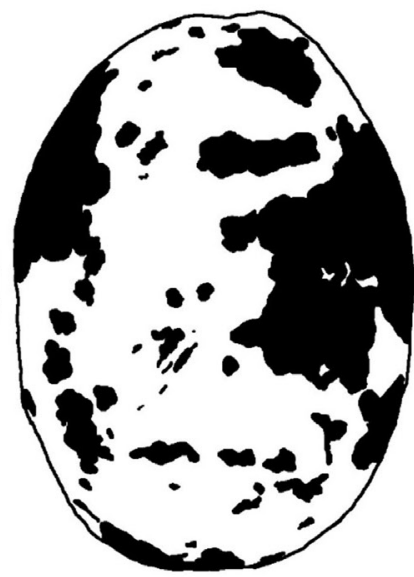

$38.0 \%$

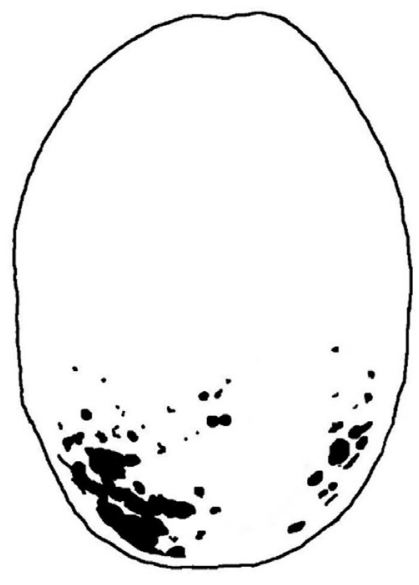

$5.0 \%$

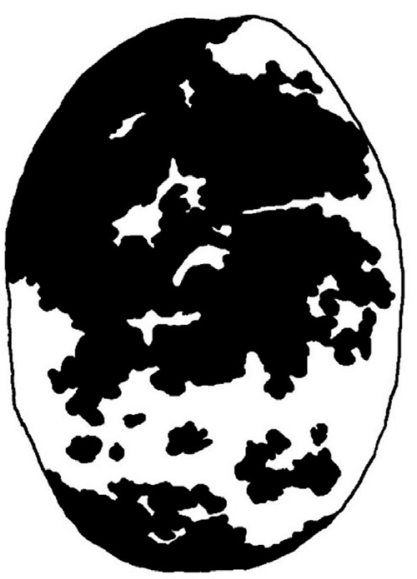

$65.0 \%$

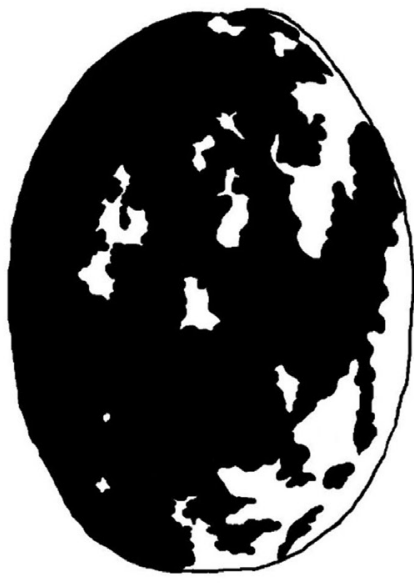

$80.0 \%$

Figure 1. Standard area diagram set (SADs) for bacterial spot severity (\%) assessment in fruits of yellow passion fruit (Passiflora edulis Sims). Brasilia, DF, Brazil, 2018. 

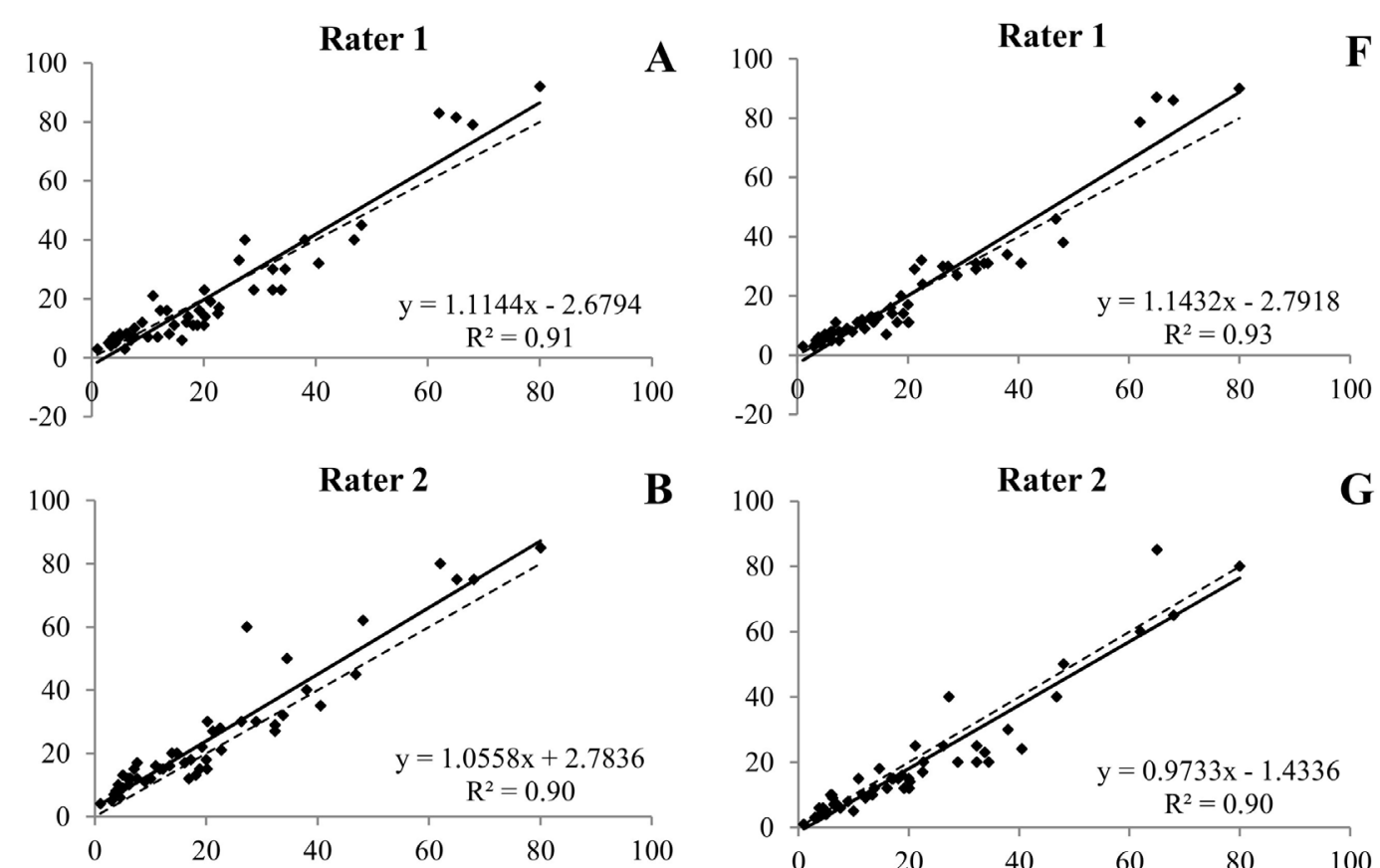

B
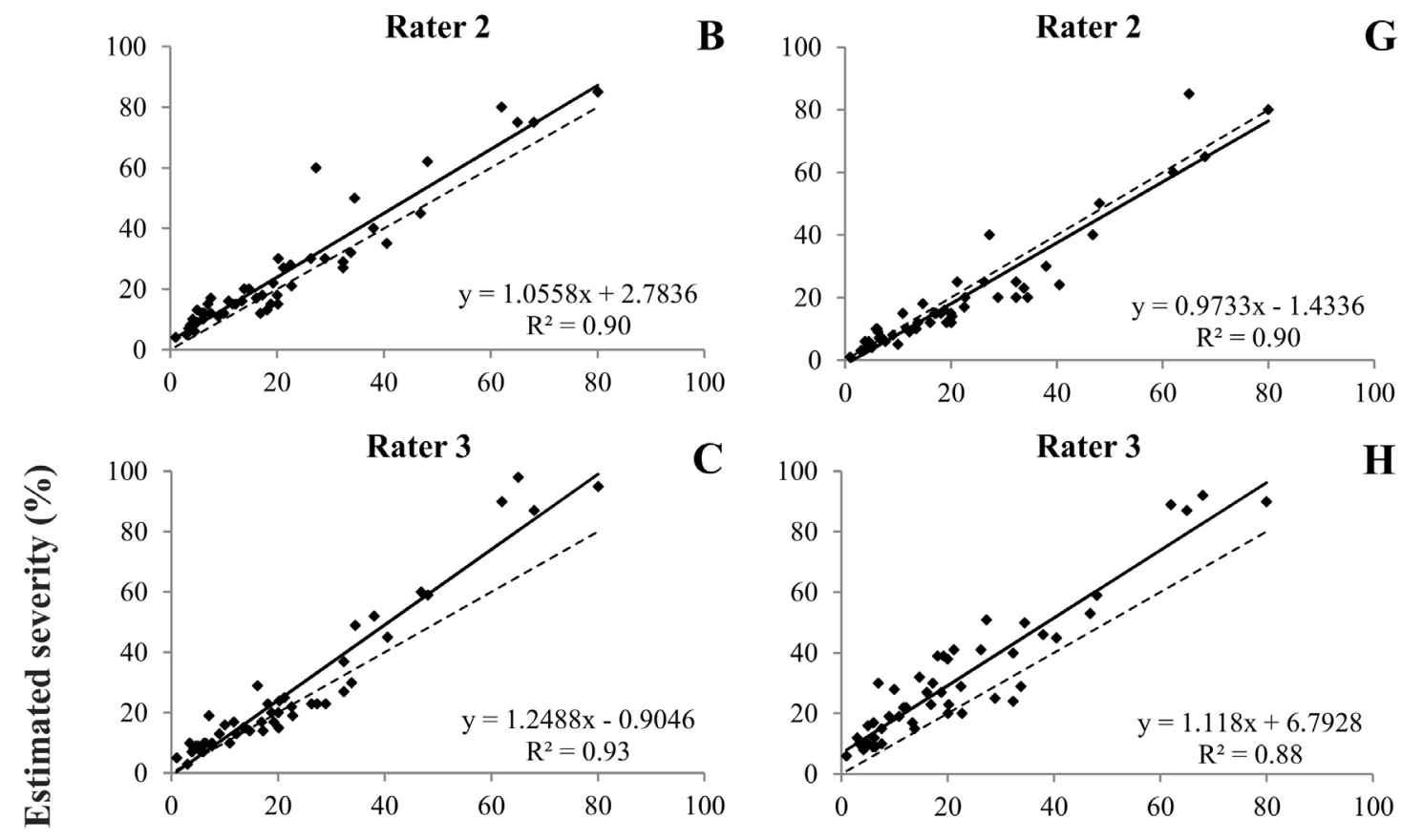

C
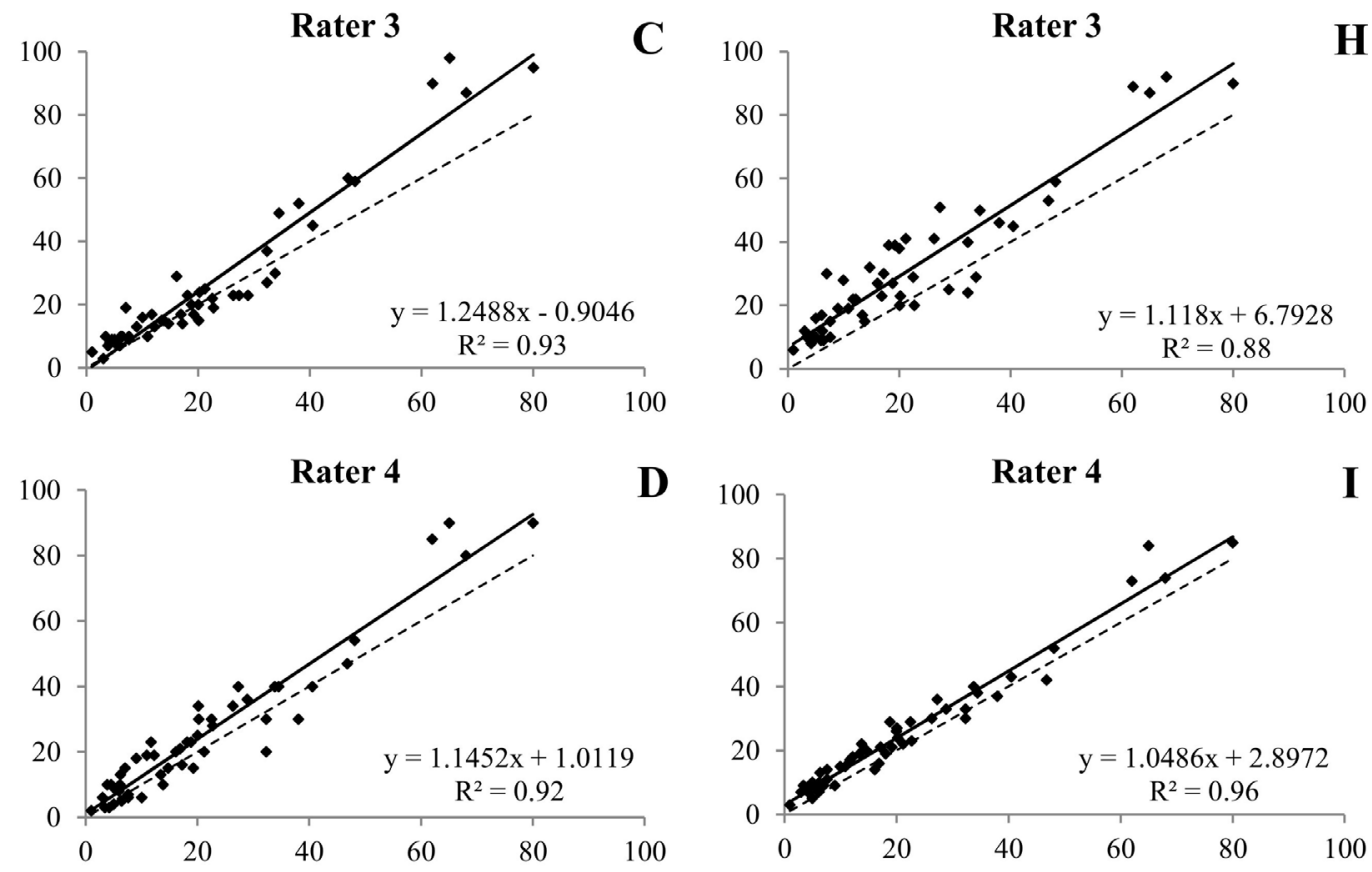

D
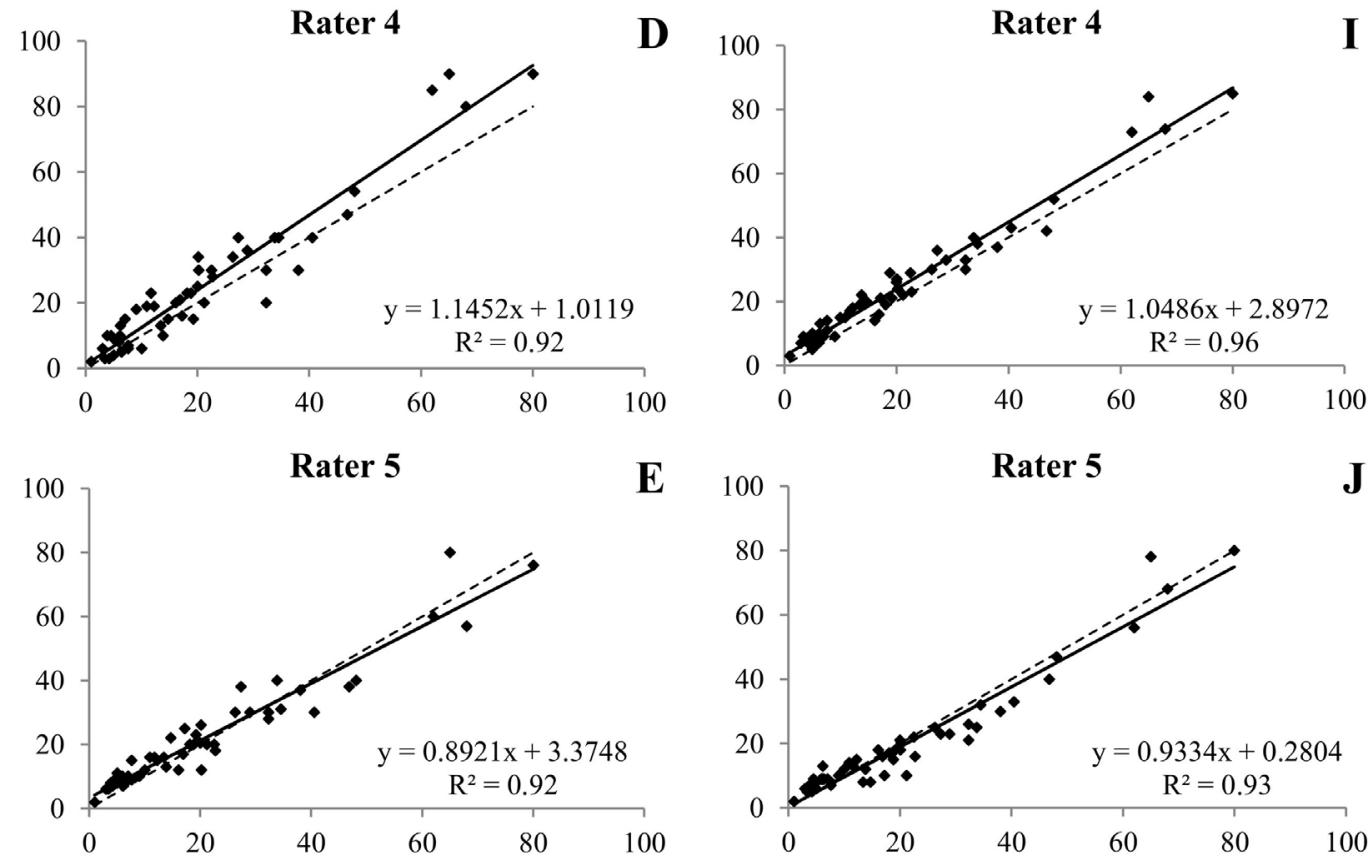

E

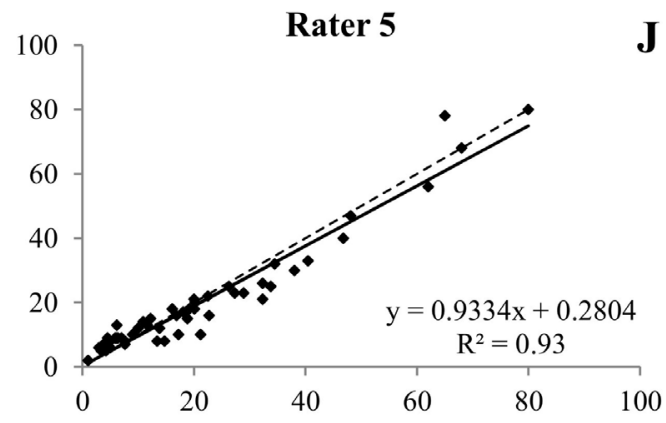

Actual severity (\%)

Figure 2. Bacterial spot (Xanthomonas axonopodis pv. passiflorae) severity on fruits of yellow passion fruit (Passiflora edulis Sims) estimated by inexperienced raters, without the aid of the standard area diagram set in the first (A-E) and second evaluations (F-J). Solid line $=$ linear regression of actual severity $\mathrm{x}$ estimated severity. Dotted line $=$ perfect agreement (linear regression of actual severity = estimated severity). Brasilia, DF, Brazil, 2018. 

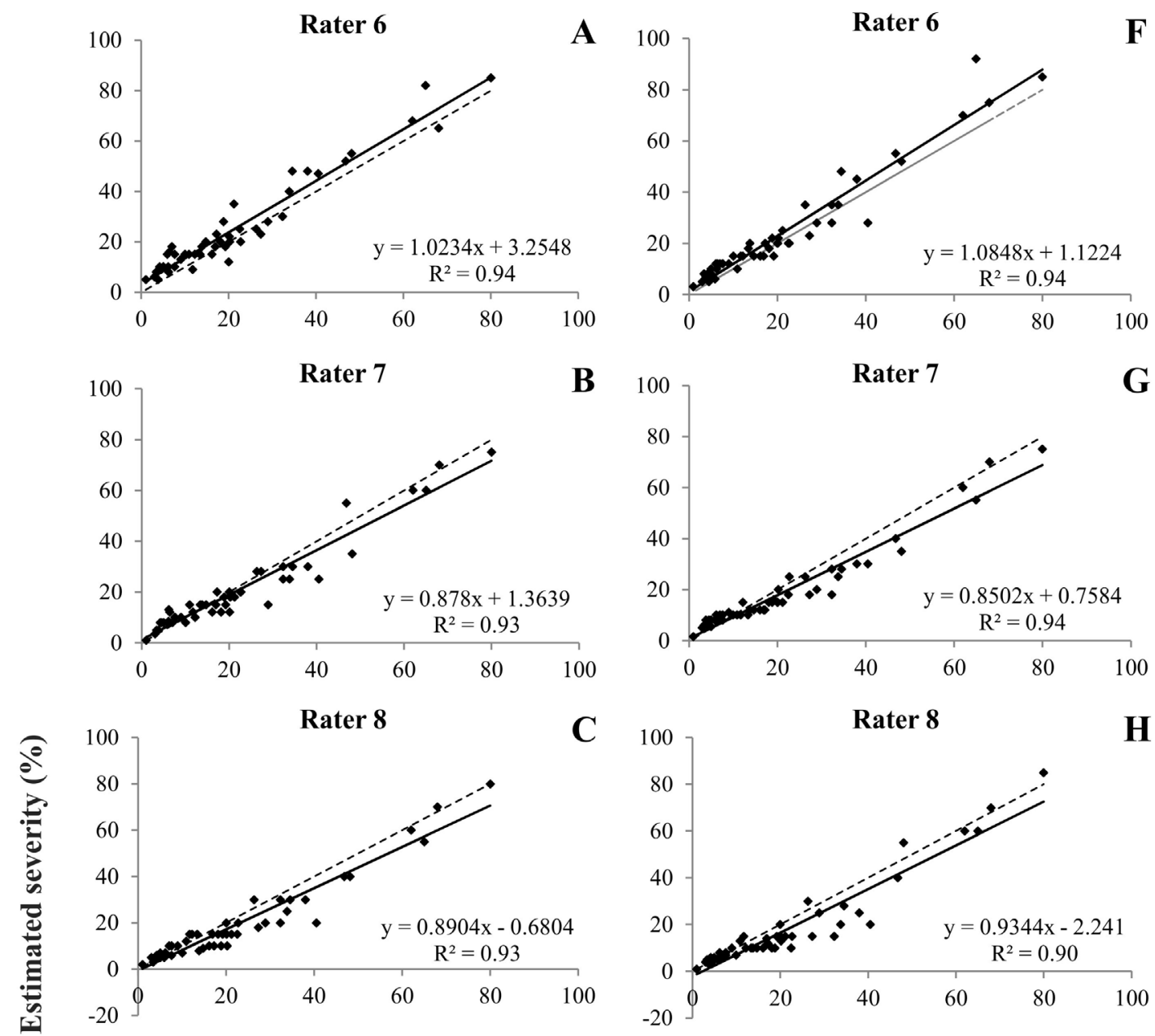

C
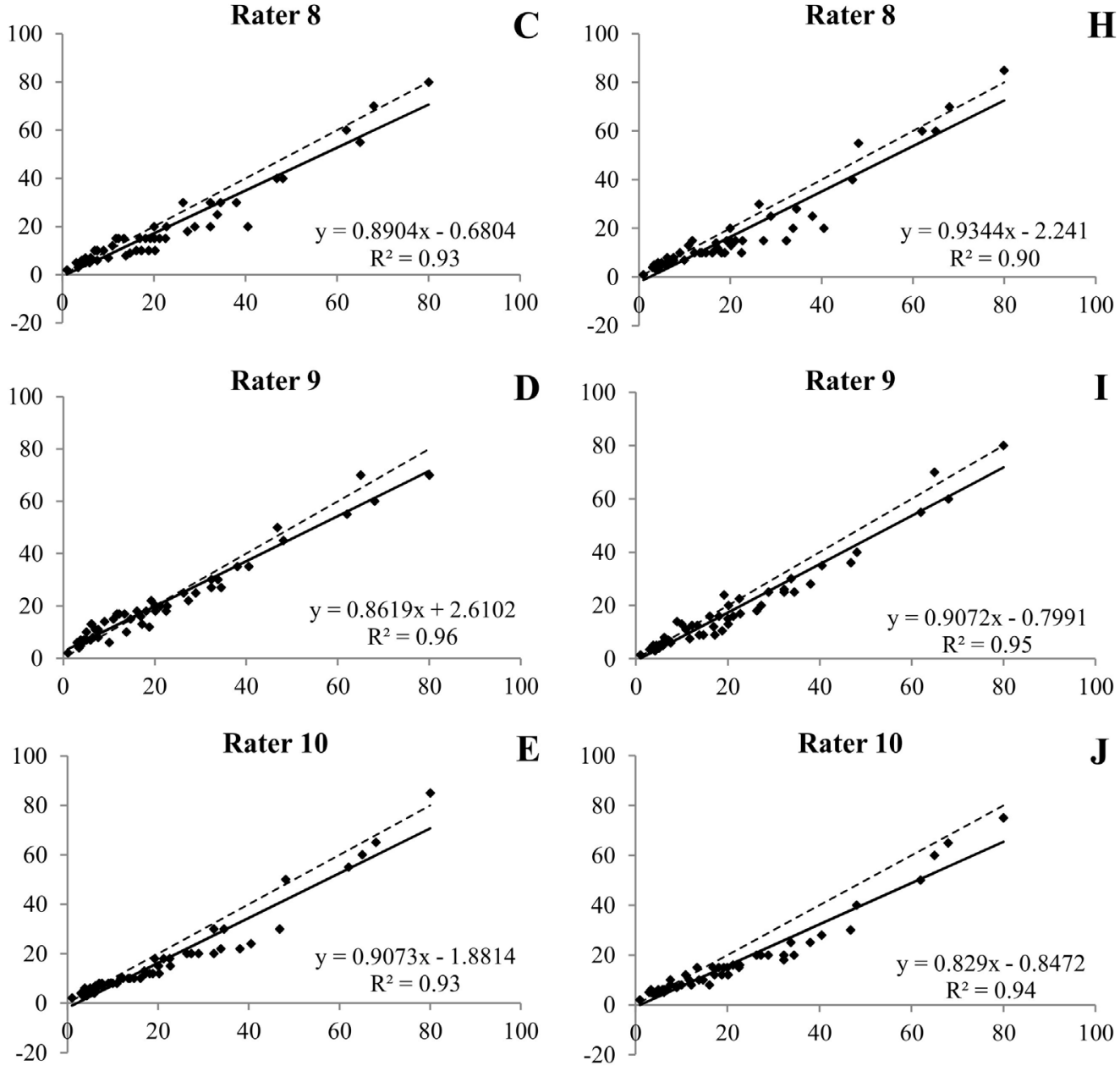

\section{Actual severity (\%)}

Figure 3. Bacterial spot (Xanthomonas axonopodis pv. passiflorae) severity on fruits of yellow passion fruit (Passiflora edulis Sims) estimated by experienced raters, without the aid of the standard area diagram set in the first (A-E) and second evaluations $(\mathrm{F}-\mathrm{J})$. Solid line $=$ linear regression of actual severity $\mathrm{x}$ estimated severity. Dotted line $=$ perfect agreement (linear regression of actual severity = estimated severity). Brasilia, DF, Brazil, 2018. 

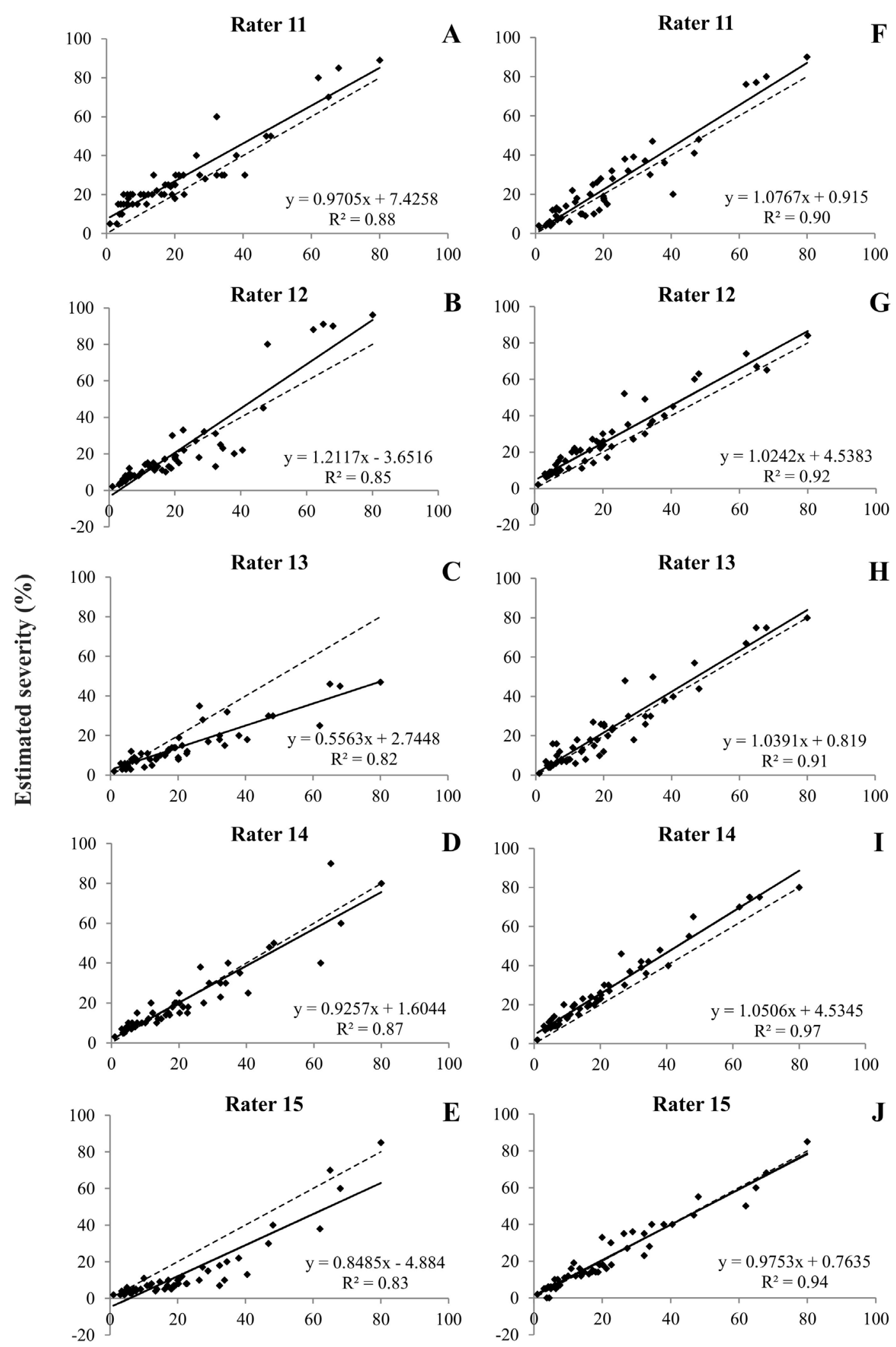

\section{Actual severity (\%)}

Figure 4. Bacterial spot (Xanthomonas axonopodis pv. passiflorae) severity on fruits of yellow passion fruit (Passiflora edulis Sims) estimated by inexperienced raters, without the aid of the standard area diagram set (SADs) in the first evaluation (A-E) and with the aid of the SADs in the second evaluation (F-J). Solid line = linear regression of actual severity $\mathrm{x}$ estimated severity. Dotted line $=$ perfect agreement (linear regression of actual severity $=$ estimated severity). Brasilia, DF, Brazil, 2018. 

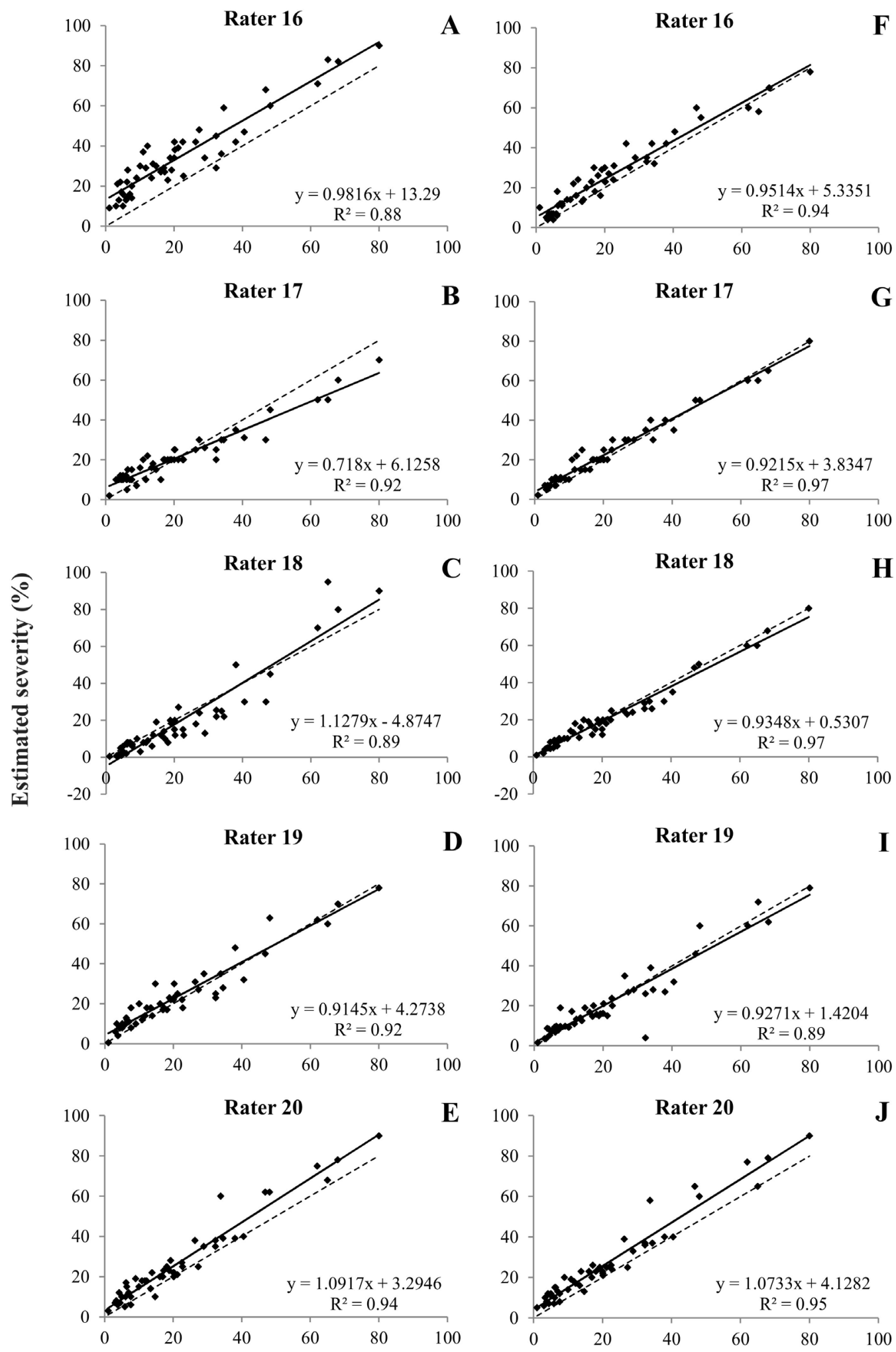

Actual severity (\%)

Figure 5. Bacterial spot (Xanthomonas axonopodis pv. passiflorae) severity on fruits of yellow passion fruit (Passiflora edulis Sims) estimated by experienced raters, without the aid of the standard area diagram set (SADs) in the first evaluation (A-E) and with the aid of the SADs in the second evaluation (F-J). Solid line = linear regression of actual severity $\mathrm{x}$ estimated severity. Dotted line $=$ perfect agreement (linear regression of actual severity $=$ estimated severity). Brasilia, DF, Brazil, 2018. 
Table 1. Intercepts $(a)$, slope coefficients $(b)$, and coefficients of determination $\left(R^{2}\right)$ of linear regression for actual severity versus estimated severity of bacterial spot (Xanthomonas axonopodis pv. passiflorae) in fruits of yellow passion fruit (Passiflora edulis Sims). Brasilia, DF, Brazil, 2018.

\begin{tabular}{|c|c|c|c|c|c|c|c|}
\hline \multirow{3}{*}{\multicolumn{2}{|c|}{$\begin{array}{c}\text { Raters } \\
\text { Inexperienced }\end{array}$}} & \multirow{2}{*}{\multicolumn{3}{|c|}{$\begin{array}{c}\text { E1 } \\
\text { No SADs }\end{array}$}} & \multirow{2}{*}{\multicolumn{3}{|c|}{$\frac{\text { E2 }}{\text { No SADs }}$}} \\
\hline & & & & & & & \\
\hline & & $a$ & $b$ & $R^{2}$ & $a$ & $b$ & $R^{2}$ \\
\hline \multirow{6}{*}{ G1 } & 1 & -2.68 & $1.11^{*}$ & 0.91 & $-2.79 *$ & $1.14^{*}$ & 0.93 \\
\hline & 2 & 2.78 & 1.06 & 0.90 & -1.43 & 0.97 & 0.90 \\
\hline & 3 & -0.90 & $1.25^{*}$ & 0.93 & $6.79 *$ & 1.12 & 0.88 \\
\hline & 4 & 1.01 & $1.15^{*}$ & 0.92 & $2.90 *$ & 1.05 & 0.96 \\
\hline & 5 & $3.37 *$ & $0.89^{*}$ & 0.92 & 0.28 & 0.93 & 0.93 \\
\hline & Mean & 0.72 & 1.09 & 0.92 & 1.15 & 1.04 & 0.92 \\
\hline \multirow{7}{*}{ G2 } & Experienced & \multicolumn{3}{|c|}{ No SADs } & \multicolumn{3}{|c|}{ No SADs } \\
\hline & 6 & $3.25 *$ & 1.02 & 0.94 & 1.12 & $1.08^{*}$ & 0.94 \\
\hline & 7 & 1.36 & $0.88^{*}$ & 0.93 & 0.76 & $0.85^{*}$ & 0.94 \\
\hline & 8 & -0.68 & $0.89^{*}$ & 0.93 & -2.24 & 0.93 & 0.90 \\
\hline & 9 & $2.61 *$ & $0.86^{*}$ & 0.96 & -0.80 & $0.91 *$ & 0.95 \\
\hline & 10 & -1.88 & $0.91 *$ & 0.93 & -0.85 & $0.83 *$ & 0.94 \\
\hline & Mean & 0.93 & 0.91 & 0.94 & -0.40 & 0.92 & 0.93 \\
\hline \multirow{7}{*}{ G3 } & Inexperienced & \multicolumn{3}{|c|}{ No SADs } & \multicolumn{3}{|c|}{ With SADs } \\
\hline & 11 & $7.43 *$ & 0.97 & 0.88 & 0.92 & 1.08 & 0.91 \\
\hline & 12 & -3.65 & $1.21^{*}$ & 0.85 & $4.54 *$ & 1.02 & 0.92 \\
\hline & 13 & $2.74 *$ & $0.56^{*}$ & 0.82 & 0.82 & 1.04 & 0.91 \\
\hline & 14 & 1.60 & 0.93 & 0.87 & $4.53 *$ & 1.05 & 0.97 \\
\hline & 15 & $-4.88^{*}$ & $0.85^{*}$ & 0.83 & 1.35 & 0.96 & 0.94 \\
\hline & Mean & 0.65 & 0.90 & 0.85 & 2.43 & 1.03 & 0.93 \\
\hline \multirow{7}{*}{ G4 } & Experienced & \multicolumn{3}{|c|}{ No SADs } & \multicolumn{3}{|c|}{ With SADs } \\
\hline & 16 & $13.29^{*}$ & 0.98 & 0.88 & $5.34 *$ & 0.95 & 0.94 \\
\hline & 17 & $6.13 *$ & $0.72 *$ & 0.92 & $3.83 *$ & $0.92 *$ & 0.97 \\
\hline & 18 & $-4.87 *$ & $1.13^{*}$ & 0.89 & 0.53 & $0.93^{*}$ & 0.97 \\
\hline & 19 & $4.27 *$ & $0.91^{*}$ & 0.92 & 1.42 & 0.93 & 0.89 \\
\hline & 20 & $3.29 *$ & $1.09^{*}$ & 0.94 & $4.13^{*}$ & 1.07 & 0.95 \\
\hline & Mean & 4.42 & 0.97 & 0.91 & 3.05 & 0.96 & 0.94 \\
\hline
\end{tabular}

$\mathrm{E} 1=$ evaluation $1 ; \mathrm{E} 2$ = evaluation 2

* indicates that the null hypothesis $(a=0$ or $b=1)$ was rejected by the t-test $(\mathrm{P} \leq 0.05)$. 
Table 2. Absolute errors (estimated severity - actual severity) of bacterial spot (Xanthomonas axonopodis pv. passiflorae) severity estimates in fruits of yellow passion fruit (Passiflora edulis Sims). Brasilia, DF, Brazil, 2018.

\begin{tabular}{|c|c|c|c|}
\hline & Raters & E1 & E2 \\
\hline \multirow{7}{*}{ G1 } & Inexperienced & No SADs & No SADs \\
\hline & 1 & $5.4 \mathrm{a}$ & $4.2 \mathrm{a}$ \\
\hline & 2 & $5.6 \mathrm{a}$ & $4.4 \mathrm{a}$ \\
\hline & 3 & $6.0 \mathrm{a}$ & $10.1 \mathrm{~b}$ \\
\hline & 4 & $5.9 \mathrm{a}$ & $4.4 \mathrm{a}$ \\
\hline & 5 & $4.2 \mathrm{a}$ & $3.6 \mathrm{a}$ \\
\hline & Mean & $5.4 \mathrm{a}$ & $5.4 \mathrm{a}$ \\
\hline \multirow{7}{*}{ G2 } & Experienced & No SADs & No SADs \\
\hline & 6 & $5.0 \mathrm{a}$ & $4.4 \mathrm{a}$ \\
\hline & 7 & $3.8 \mathrm{a}$ & $4.1 \mathrm{a}$ \\
\hline & 8 & $4.3 \mathrm{a}$ & $4.9 \mathrm{a}$ \\
\hline & 9 & $3.5 \mathrm{a}$ & $3.8 \mathrm{a}$ \\
\hline & 10 & $4.5 \mathrm{a}$ & $5.1 \mathrm{a}$ \\
\hline & Mean & $4.2 \mathrm{a}$ & $4.5 \mathrm{a}$ \\
\hline \multirow{7}{*}{ G3 } & Inexperienced & No SADs & With SADs \\
\hline & 11 & $7.9 \mathrm{~b}$ & $5.6 \mathrm{a}$ \\
\hline & 12 & $6.1 \mathrm{a}$ & $5.8 \mathrm{a}$ \\
\hline & 13 & $7.9 \mathrm{~b}$ & $4.4 \mathrm{a}$ \\
\hline & 14 & $4.3 \mathrm{a}$ & $5.6 \mathrm{a}$ \\
\hline & 15 & $8.7 \mathrm{~b}$ & $3.4 \mathrm{a}$ \\
\hline & Mean & $7.0 \mathrm{~b}$ & $5.0 \mathrm{a}$ \\
\hline \multirow{7}{*}{ G4 } & Experienced & No SADs & With SADs \\
\hline & 16 & $13.0 \mathrm{~b}$ & $5.0 \mathrm{a}$ \\
\hline & 17 & $5.2 \mathrm{~b}$ & $3.1 \mathrm{a}$ \\
\hline & 18 & $5.8 \mathrm{~b}$ & $2.6 \mathrm{a}$ \\
\hline & 19 & $4.4 \mathrm{a}$ & $3.8 \mathrm{a}$ \\
\hline & 20 & $5.7 \mathrm{a}$ & $5.9 \mathrm{a}$ \\
\hline & Mean & $6.8 \mathrm{~b}$ & $4.1 \mathrm{a}$ \\
\hline
\end{tabular}

$\mathrm{E} 1=$ evaluation $1 ; \mathrm{E} 2$ = evaluation 2

*Different letters in the same row indicate significant differences (Student's t-test, $\mathrm{P} \leq 0.05$ ).

Table 3. Mean maximum error in absolute value (MEAV), at 10\% $(\mathrm{x} \pm 10)$ and $5 \%(\mathrm{x} \pm 5)$ error range of the severity estimates in relation to the actual severity of bacterial spot (Xanthomonas axonopodis pv. passiflorae) in fruits of yellow passion fruit (Passiflora edulis Sims). Brasília, DF, Brasil, 2018.

\begin{tabular}{cccccc}
\hline \multirow{2}{*}{ Evaluation } & \multirow{2}{*}{ Parameters } & \multicolumn{5}{c}{ Groups } \\
\cline { 3 - 6 } & MEAV & 25.3 & 16.0 & 29.8 & 23.2 \\
\multirow{2}{*}{$\mathbf{1}$} & $\mathbf{0} \mathbf{x} \pm \mathbf{5}$ & 61.2 & 70.4 & 54.0 & 61.6 \\
& $\mathbf{\%} \mathbf{x} \pm \mathbf{1 0}$ & 86.8 & 94.0 & 74.8 & 88.4 \\
& & & & & \\
& $\mathbf{M E A V}$ & 20.2 & 17.9 & 20.1 & 17.6 \\
$\mathbf{2}$ & $\mathbf{\%} \mathbf{x} \pm \mathbf{5}$ & 62.0 & 68.4 & 62.0 & 72.0 \\
& $\mathbf{\%} \mathbf{x} \pm \mathbf{1 0}$ & 86.0 & 91.6 & 89.6 & 93.6 \\
\hline
\end{tabular}


Table 4. Correlation coefficient between estimated severity and actual severity $(r)$, bias correction factor $\left(C_{b}\right)$, and Lin's concordance correlation coefficient ( $\left.\boldsymbol{\rho}_{c}\right)$ for bacterial spot (Xanthomonas axonopodis pv. passiflorae) severity estimates in fruits of yellow passion fruit (Passiflora edulis Sims). Brasilia, DF, Brazil, 2018.

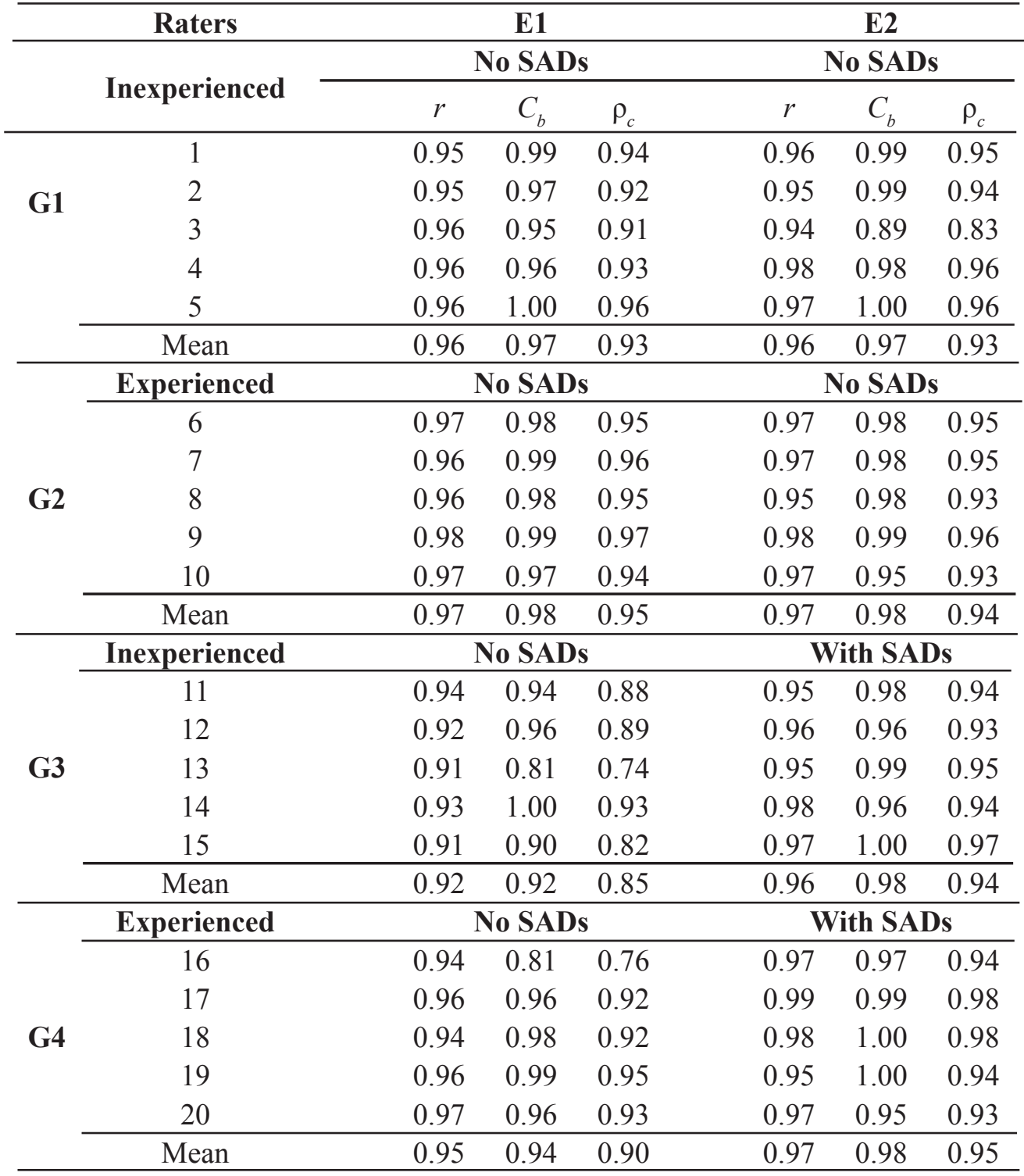

E1 = evaluation $1 ;$ E2 = evaluation 2 


\section{Conclusions}

The proposed SADs increased the ability of the raters to accurately and precisely estimate the disease severity, showing to be efficient to increase the agreement between the estimated values and the actual values and the reproducibility of estimates among raters. Therefore, the SADs can be used in epidemiological studies, in the evaluation of control strategies for this disease, and in studies on the resistance to bacterial spot in plant breeding programs. They can also help reduce the training time of raters, so that accurate and precise estimates are achieved more quickly.

\section{Acknowledgments}

This study was financed, in part, by the Coordenação de Aperfeiçoamento de Pessoal de Nível Superior - Brasil (CAPES) - Finance Code 001. The authors acknowledge the raters for their contribution to the SADs validation. The authors also thank Dr. Ildeu Soares Martins and Dr. Michelle Souza Vilela for their guidance with the statistical analyses.

\section{References}

BATISTTI, M.; KRAUSE, W.; BARÉA, M.; ARAUJO, D. V.; PALÚ, E. G. Resistência à verrugose de cultivares de maracujazeiro amarelo sob diferentes métodos de inoculação. Enciclopédia Biosfera, Goiânia, v.9, n.16, p.2710-2720, 2013.

BELASQUE JÚNIOR, J.; BASSANEZI.R.B., SPÓSITO, M.B.; RIBEIRO, L.M.; JESUS JÚNIOR, W.C.; AMORIM, L. Escalas diagramáticas para avaliação da severidade do cancro cítrico. Fitopatologia Brasileira, Brasília, DF, v.30, n.4, p.387-393, 2005.

BOCK, C.H.; POOLE, G.; PARKER, P.E.; GOTTWALD, T.R. Plant disease severity estimated visually, by digital photography and image analysis, and by hyperspectral imaging. Critical Reviews in Plant Sciences, London, v.29, p.59-107, 2010.

BRAIDO, R.; GONÇALVES-ZULIANI, A.M.O.; NOCCHI, P.T.R.; BELASQUE JUNIOR, J.; JANEIRO, V.; BOCK, C.H., NUNES, W.M.C. A standard area diagram set to aid estimation of the severity of Asiatic citrus canker on ripe sweet orange fruit. European Journal of Plant Pathology, Dordrecht, v.141, p.327-337, 2015.

CAMPBELL, C.L.; MADDEN, L.V. Introduction to plant disease epidemiology. New York: John Wiley, 1990. $532 \mathrm{p}$.
CITADIN, I.; ASSMANN, A.P.; MAZARO, S.M.; GOUVEA, A.; DANNER, M.A.; MALAGI, G. Escala diagramática para avaliação da severidade de bacteriose em pessegueiro. Revista Brasileira Fruticultura, Jaboticabal, v.30, n.2, p.327-330, 2008.

CORREIA, K.C.; QUEIROZ, J.V.J.; MARTINS, R.B.; NICOLI, A.; DEL PONTE, E.M.; MICHEREFF, S.J. Development and evaluation of a standard area diagram set for the severity of phomopsis leaf blight on eggplant. European Journal of Plant Pathology, Dordrecht, v.149, p.269-276, 2017.

CRUZ, C.D. Genes: a software package for analysis in experimental statistics and quantitative genetics. Acta Scientiarum: Agronomy, Maringá, v.35, n.3, p.271-276, 2013.

DE BEM, B.P.; BOGO, A.; EVERHART, S.E.; CASA, R.T.; GONÇALVES, M.J.; MARCON FILHO, J.L.; RUFATO, L.; SILVA, F.N.; ALLEBRANDT, R.; CUNHA, I.C. Effect of four training systems on the temporal dynamics of downy mildew in two grapevine cultivars in southern Brazil. Tropical Plant Pathology, Brasília, DF, v.41, n.6, p. 370-379, 2016.

DE PAULA, P.V.A.A.; POZZA, E.A.; SANTOS, L.A.; CHAVES, E.; MACIEL, M.P.; PAULA, J.C.A. Diagrammatic scales for assessing brown eye spot (Cercospora coffeicola) in red and yellow coffee cherries. Journal of Phytophatology, Utrecht, v.164, n.10, p.791800, 2016.

DUAN, J.; ZHAO, B.; WANG, Y.; YANG, W. Development and validation of a standard area diagram set to aid estimation of bacterial spot severity on tomato leaves. European Journal of Plant Pathology, Dordrecht, v.142, p.665-675, 2015.

FALEIRO, F.G.; JUNQUEIRA, N.T.V.; BRAGA, M.F.; OLIVEIRA, E.J.; PEIXOTO, J.R.; COSTA, A.M. Germoplasma e melhoramento genético do maracujazeiro: histórico e perspectivas. Planaltina: Embrapa Cerrados, 2011. 36p.

FISCHER, I.H.; ALVES, S.A.M.; ALMEIDA, A.M.; ARRUDA, M.C.; BERTANI, R.M.A.; GARCIA, M.J.M. Elaboração e validação de escala diagramática para quantificação da severidade da antracnose em frutos de maracujá amarelo. Summa Phytopathologica, Piracicaba, v.35, n.3, p.226-228, 2009.

FISCHER, I.H.; REZENDE, J.A.M. Diseases of passion flower. Pest Technology, Manchester, v.2, n.1, p.1-19, 2008. 
GONZÁLEZ-DOMÍNGUEZ, E.; MARTINS, R.B.; DEL PONTE, E.M.; MICHEREFF, S.J.; GARCÍA-JIMÉNEZ, J.; ARMENGOL, J. Development and validation of a standard area diagram set to aid assessment of severity of loquat scab on fruit. European Journal of Plant Pathology, Dordrecht, v.139, p.413-422, 2014.

GYAWALI, S.; VERMA, R.P.S.; KUMAR, S.; BHARDWAJ, S.C.; GANGWAR, O.P.; SELVAKUMAR, R.; SHEKHAWAT, P.S.; REHMAN, S.; SHARMAPOUDYAL, D. Seedling and adult-plant stage resistance of a world collection of barley genotypes to stripe rust. Journal of Phytopathology, Berlin, v.166, n.1, p.18-27, 2018.

HAU, B.; KRANZ, J.; KONIG, R. Fehler beim Schätzen von Befallsstärken bei Pflanzenkrankheiten. Zeitschrift für Pflanzenkrankheiten und Pflanzenschutz, Stuttgart, v.96, p.649-674, 1989.

ISHIDA, A. K. N.; HALFED-VIEIRA, B. A. Manchabacteriana do maracujazeiro (Xanthomonas axonopodis pv. passiflorae): etiologia e estratégias de controle. Belém: Embrapa Amazônia Oriental, 2009. 23 p.

JUNQUEIRA, N.T.V.; SUSSEL, A.A.B.; JUNQUEIRA, K.P.; ZACARONI, A.B.; BRAGA, M.F. Doenças. In: FALEIRO, F.G.; JUNQUEIRA, N.T.V. (Ed.). Maracujá: o produtor pergunta, a Embrapa responde. Brasília, DF: Embrapa Cerrados, 2016. p. 169-180. (Coleção 500 perguntas, 500 respostas).

KRANZ, J. Measuring plant disease. In: KRANZ, J.; ROTEM, J. (Ed.). Experimental techniques in plant disease epidemiology. Heidelberg: Springer-Verlag, 1988. p. 35-50.

KUDO, A.S.; PEIXOTO, J.R.; JUNQUEIRA, N.T.V.; BLUM, L.E.B. Suscetibilidade de genótipos de maracujazeiro-azedo à septoriose em casa de vegetação. Revista Brasileira de Fruticultura, Jaboticabal, v.34, n.1, p.200-205, 2012.

LAGE, C.A.C.; MAROUELLI, W.A.; DUARTE, H.S.S.; CAFÉ-FILHO, A.C. Standard area diagrams for assessment of powdery mildew severity on tomato leaves and leaflets. Crop Protection, London, v.67, p.26-34, 2015.
LIMA, H.E.; NECHET, K.L.; HALFELD-VIEIRA, B.A.; OLIVEIRA, J.R.; DUARTE, H.S.S.; QUEIROZ, E.S.; OLIVEIRAM F.L. Elaboração e validação de escalas diagramáticas para avaliação da severidade da manchabacteriana do feijão-caupi em cultivares com trifólios morfologicamente distintos. Ciência Rural, Santa Maria, v.43, n.10, p.1735-1743, 2013.

LIN, L.I. A concordance correlation coefficient to evaluate reproducibility. Biometrics, Oxford, v.45, p.255-268, 1989.

MARCUZZO, L.L; DUARTE, T.S.; ROSA NETO, A.J.; HOFFMANN, F. Efeito de fosfito de potássio e de fungicidas no controle da cercosporiose (Cercospora beticola) da beterraba. Summa Phytopathologica, Piracicaba, v.42, n.2, p.186-187, 2016.

NASCIMENTO, A.R.P.; MICHEREFF, S.J.; MARIANO, R.L.R.; GOMES, A.M.A. Elaboração e validação de escala diagramática para cancro bacteriano da videira. Summa Phytopathologica, Piracicaba, v.31, n.1, p.59-64, 2005.

NOGUEIRA, I. Caracterização agronômica e físicoquímica de progênies de maracujazeiro azedo (Passiflora edulis Sims) no Distrito Federal. 2016. 113 f. Dissertação (Mestrado em Agronomia) -Universidade de Brasília, Brasília, DF, 2016.

NUÑEZ, A. M. P.; MONTEIRO, F. P.; PACHECO, L. P.; RODRÍGUEZ, G. A. A.; NOGUEIRA, C. C. A.; PINTO, F. A. M. F.; MEDEIROS, F. A. V.; SOUZA, J. T. Development and validation of a diagrammatic scale to assess the severity of black rot of crucifers in Kale. Journal of Phytopathology, Berlin, v.165, n.3, p.195203, 2017.

NUTTER JR., F. W.; SCHULTZ, P. M. Improving the accuracy and precision of disease assessment: selection of methods and use of computer-aided training programs. Canadian Journal of Plant Pathology, v. 17, n. 2, p. 174-184, 1995.

NUTTER, F.W.; WORAWITLIKIT, O. Disease.Pro: a computer program for evaluating and improving a person ability to assess disease proportion. Phytopathology, St Paul, v.79, p.1135, 1989. 
PEREIRA, A.B.; NOVA, N.A.V.; RAMOS, V.J.; PEREIRA, A.R. Potato potential yield based on climatic elements and cultivar characteristics. Bragantia, Campinas, v.67, n.2, p.327-334, 2008.

PERUCH, L.A.M.; COLARICCIO, A.; SCHROEDER, A.L. Sintomas e controle das principais doenças do maracujazeiro (Passiflora edulis f. flavicarpa) em Santa Catarina. Agropecuária Catarinense, Florianópolis, v.24, n.2, p.42-45, 2011.

SANTOS, P.H.D.; MUSSI-DIAS, V.; FREIRE, M.G.M.; CARVALHO, B.M.; SILVEIRA, S.F. Diagrammatic scale of severity for postharvest black rot (Ceratocystis paradoxa) in coconut palm fruits. Summa Phytopathologica, Botucatu, v.43, n.4, p.269-275, 2017.

SCHNEIDER, C.A.; RASBAND, W.S.; ELICEIRI, K.W. NIH Image to Image J: 25 years of image analysis. Nature Methods, New York, v.9, p.671-675, 2012.

TOMERLIN, J.R.; HOWELL, T.A. Distrain: a computer program for training people to estimate disease severity on cereal leaves. Plant Disease, Washington, v.72, p.455459, 1988.
VENTURINI, M.T.; SANTOS, L.R.; OLIVEIRA, E.J. Development of a diagrammatic scale for the evaluation of postharvest physiological deterioration in cassava roots. Pesquisa Agropecuária Brasileira, Brasília, DF, v.50, n.8, p.658-668, 2015.

VIEIRA, R.A.; MESQUINI, R.M.; SILVA, C.N.; HATA, F.T.; TESSMANN, D.J.; SCAPIM, C.A. A new diagrammatic scale for the assessment of northern corn leaf blight. Crop Protection, London, v.56, p.55-57, 2014.

VIANA, C.A.S.; PIRES, M.C.; PEIXOTO, J.R.; JUNQUEIRA, N.T.V.; BLUM, L.E.B. Genótipos de maracujazeiro-azedo com resistência à bacteriose. Bioscience Journal, Uberlândia, v.30, Supl. 2, p.591598, 2014.

YADAV, N.V.; VOS, S.M.; BOCK, C.H.; WOOD, B.W. Development and validation of standard area diagrams to aid assessment of pecan scab symptoms on fruit. Plant Pathology, London, v.62, n.2, p.325-335, 2013. 